\title{
The Impact of BK Virus and Cytomegalovirus Infections on Graft in Renal Transplant Patients: Experience of a Tertiary Hospital in Turkey Böbrek Nakli Hastalarında BK Virüs ve Sitomegalovirüs Enfeksiyonlarının Greft Üzerine Etkisi: Türkiye'den Bir Üçüncü Basamak Hastane Deneyimi
}

\author{
Şükran KÖSE1, Sabri ATALAY1 ${ }^{1}$, Yıldız ULU2, Ufuk SÖNMEZ1', Süheyla SERIN SENGER ${ }^{1}$ \\ ${ }_{1}^{1}$ Health Sciences University, Tepecik Training and Research Hospital, Clinic of Infectious Diseases and Clinical Microbiology, Izmir, Turkey \\ 2Zonguldak Devrek State Hospital, Clinic of Infectious Diseases and Clinical Microbiology, Zonguldak, Turkey
}

\section{Abstract}

Introduction: BK virus (BKV) and cytomegalovirus (CMV) infections are common in renal transplant patients. In this retrospective study, we investigated the frequency of BKV and CMV infections and their effects on graft.

Materials and Methods: The data of 118 renal transplant recipients who were transplanted and followed-up between January 2010 and January 2011 were reviewed. Demographic characteristics, biochemical data, BKV and CMV DNA levels by polymerase chain reaction (QIAGEN, Hilden, Germany) were investigated. The patients were followed-up monthly in the first six months and then every three months.

Results: A total of 118 patients were included in the study. BK viraemia was detected in $12(10.2 \%)$ patients and the DNA level of BKV was >104 copies/mL in five cases. Three patients with elevated creatinine and compatible renal biopsy findings were considered to have BKV-associated nephropathy (BKVAN). With the reduction of immunosuppressive treatment, viraemia was reduced and creatinine levels decreased within normal levels. Cytomegalovirus DNA was found to be positive in $23(19.5 \%)$ patients, and was $>500$ copies $/ \mathrm{mL}$ in 4 (3.4\%) patients. The viraemia in these four patients has decreased after antiviral therapy. No CMV related disease were found in any of the patients. Cytomegalovirus DNA positivity at low levels were also detected in three patients who were diagnosed with BKVAN. None of the patients developed rejection.

Conclusion: BK and CMV infections in kidney transplant patients are common and can be seen together. However, graft dysfunction and rejection rates are low with close monitoring, early diagnosis and treatment. Randomized, controlled studies with larger patient groups are necessary in order to determine the viral threshold levels associated with graft dysfunction or rejection, to decide the optimal management and to explain the role of concomitant infection.

Keywords: BK, kidney, transplantation, infection, ciprofloxacin

\section{Öz}

Giriş: BK virüs (BKV) ve sitomegalovirüs (CMV) enfeksiyonları böbrek nakli hastalarında yaygın olarak görülür. Bu retrospektif çalışmada BKV ve CMV enfeksiyon sıklığı ve greft üzerine etkileri araştırılmıştır.

Gereç ve Yöntem: Ocak 2010 ve Ocak 2011 tarihleri arasında böbrek nakli uygulanan ve takip edilen 118 böbrek nakil alıcısının verileri retrospektif olarak değerlendirildi. Hastaların demografik özellikleri, biyokimyasal veriler ve polimeraz zincir reaksiyonu (QIAGEN, Hilden, Germany) yöntemiyle BKV ve CMV DNA seviyeleri araştırıldı. Hastalar önce altı ay aylık olarak, daha sonra üç aylık periyotlarla izlenmiştir.

Bulgular: Çalışmaya toplam 118 hasta alınmıştır. BK viremisi $12(\% 10,2)$ hastada saptanmış olup, beş olguda BKV DNA düzeyi >104 kopya/mL olarak tespit edilmiştir. Kreatinin yüksekliği de olan ve biyopsi bulguları uyumlu bulunan üç hasta, BKV ile ilişkili nefropati olarak değerlendirilmiştir. İmmünsüpresif tedavinin azaltılması ile viremi gerilemiş ve kreatinin seviyeleri normal düzeye gelmiştir. Sitomegalovirüs DNA, 23 (\%19,5) hastada pozitif, dördünde $(\% 3,4)$ ise $>500$ kopya/mL olarak bulunmuştur. Bu dört hastanın viremisi antiviral tedavi sonrası gerilemiştir. Hastaların hiçbirinde CMV hastalığı ile ilişkili klinik veya laboratuvar bulgusu tespit edilmemiştir. BK virüs ile ilişkili nefropati tanısı alan üç hastada aynı zamanda düşük düzeyde CMV DNA pozitifliği tespit edilmiştir. Hastaların hiçbirinde rejeksiyon gelişmemiştir.

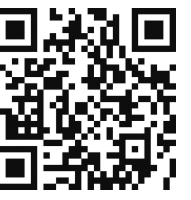


Sonuç: Böbrek nakli hastalarında BK ve CMV enfeksiyonları sıktır ve birlikte görülebilir. Ancak yakın takip, erken tanı ve tedavi ile greft disfonksiyon ve rejeksiyon oranları düşüktür. Greft disfonksiyonu ve rejeksiyonu ile ilişkili viral eşik seviyeyi belirlemek, optimal yaklaşıma karar vermek ve eş zamanlı görülen enfeksiyonların rolünü açıklamak amacıyla daha fazla hasta ile yapılmış randomize, kontrollü çalışmalar gereklidir.

Anahtar Kelimeler: BK, böbrek, nakil, enfeksiyon, siprofloksasin

\section{Introduction}

Solid organ transplantation (SOT) is the major treatment method for organ failures. The incidence of organ rejection has been reduced with the introduction of potent immunosuppressive agents in recent years; and survival rates for grafts and recipients increased. However, the potent immunosuppressive treatment regimens rsise some issues for the patients. Two major complications, infection and malignancy, are the results of the lifelong immunosuppression needed to maintain allograft function. The spectrum of the infections observed in SOT recipients usually varies depending on the period after the transplantation, but the infections such as reactivation of latent infection in the recipient or in the graft are typical. Two infections namely BK viruses (BKV) and cytomegalovirus (CMV) latent infections are common. These infections have negative impact on long-term graft function and patient survival. The infections developing in SOT patients are generally asymptomatic and difficult to diagnose and treat. Therefore, a close follow-up and treatment is required[1].

BK virus, a member of the human polyomavirus family, is a non-enveloped double-stranded DNA virus. There are several possible modes of transmission of the virus: via the respiratory tract, through saliva, blood, uro-oral, faecal-oral route, and via sexual contact. Transplacental transmission is also possible[2]. The seropositivity rate is approximately $80 \%$, although varies depending on the age and the region. In a study of 1123 healthy subjects in Turkey, 78.5\% of participants were BKV seropositive[3]. Primary BKV infections often develop in childhood and are typically subclinical following the primary infection; BKV remains latent in the kidney cells and lymphocytes, and is reactivated under conditions such as immunosuppression. Reactivation might occur during steroid use, hematological malignancies, and autoimmune disorders. However, the patient group most affected by BKV is the group of kidney and bone marrow transplant recipients[4,5].

BK virus-associated nephropathy (BKVAN) due to reactivation in renal transplant recipients is a leading cause of graft loss[6]. BK virus-associated nephropathy causes tubulointerstitial nephritis that can mimic rejection as it is characterized by an increased creatinine level. The treatment dilemma is that the decrease in immunosuppression that is needed to treat infection is opposite to the increases that are needed to treat rejection[7]. Therefore, the etiology of the creatinine elevation in renal transplant recipients must be well clarified.

Another critical factor for the renal transplant recipients is CMV. Cytomegalovirus infections are common worldwide. The virus which may be present in blood, sweat, saliva, semen, cervicovaginal secretions, tear, and urine without any symptoms, may be transmitted through the transplacental route, sexual intercourse, blood transfusion and organ transplantation, and close contact with asymptomatic patients shedding the virus. Cytomegalovirus seropositivity can be detected in 90-100\% of adults in developing countries. In studies carried out in Turkey, the seroprevalence of CMV in adults has been reported in a range of $85-95 \%[8]$. The primary infection is typically subcliinical and develops mostly in childhood while the virus may remain latent throughout life. The primary infection has a subclinical progress or manifests itself as mononucleosis syndrome in a normal host. However, in an immunocompromised host, primary infection may cause severe manifestations with fatal outcomes such as CMV disease (pneumonia, hepatitis, colitis, meningoencephalitis, crescentic glomerulonephritis, pancreatitis)[9,10]. Cytomegalovirus infections are one of the most prevalent opportunistic infections among transplant recipients. Cytomegalovirus infection usually occurs within 1-4 months after transplantation without prophylaxis. It may be associated with acute and chronic graft loss[11]. There are various risk factors for CMV infection such as environmental, geographical and economical. Other factors include host conditions such as age, co-morbidities, underlying disease, leukopenia, Iymphopenia, cold ischemia time and immunosuppressive protocol (type of medication, timing, and duration of use). One of the most definitive risk factors has been reported in studies is CMV incompatibility between donor and recipient, especially when the donor is positive and recipient is negative[12].

In this respect, both BKV and CMV infections are significant issues for renal transplant recipients. In order to prevent graft dysfunction or rejection, early diagnosis is essential for the antiviral treatment or to adjust the immunosuppressive therapy. Regular screening for both viruses is required after transplantation[13].

In this study, it was aimed to investigate the prevalence of BKV and CMV infections in renal transplant recipients and to evaluate the relationship of BKV and CMV infections with graft dysfunction and survival. 


\section{Materials and Methods}

Data of 118 renal transplant recipients, who were transplanted and followed up at our hospital between January 2010 and January 2011, were reviewed.

Demographic features, complete blood count, urea, creatinine, urinalysis results and BKV, CMV DNA viral loads were obtained from medical files of the patients. BK virus DNA polymerase chain reaction (PCR) (OIAGEN, Hilden, Germany) was performed every month in the first six months, then every three months and/or when creatinine elevation was detected. The diagnosis of presumptive BKVAN is established in the presence of renal allograft dysfunction and a positive BKV DNA PCR result. Patients with (a) an acute tubular necrosis-like picture or (b) interstitial nephritis mimicking acute rejection or (c) chronic allograft nephropathy findings in the kidney biopsy, were defined as proven BKVAN[14].

Cytomegalovirus DNA was also tested by real time PCR (QIAGEN, Hilden, Germany) monthly in the first six months after transplantation, then every three-months for one year and/or in case of suspected CMV disease or graft rejection. All patients and/or donors were seropositive for CMV, thus, valganciclovir $900 \mathrm{mg} /$ day prophylaxis was given for three-month duration. Cytomegalovirus infection was defined if CMV DNA was detected in blood without any symptoms. Cytomegalovirus disease is defined by evidence of CMV infection with symptoms attributable to the disease. Cytomegalovirus disease was subclassified into CMV viral syndrome or tissue-invasive disease. Cytomegalovirus syndrome was defined when one or more of findings such as, fever, leukopenia, trombocytopenia, elevation in liver enzymes, were positive in CMV-infected patients. If any endorgan involvement was detected, it was defined as tissueinvasive disease[14].

\section{Results}

A total of 118 renal transplant recipients, 61 females (52\%) and 57 males (48\%), were included in the study. The mean age of the patients was 37 years (17-55). BK virus DNA was detected to be positive $\left(29.2-5.4 \times 10^{6}\right.$ copies $\left./ \mathrm{mL}\right)$ in 12 (10.2\%) patients. The level was over $10^{4}$ copies $/ \mathrm{mL}$ in five (4.2\%) patients. Review of patients with significantly high BKV DNA levels with respect to the period of transplantation showed that three patients were in >12 months period, one in 6-12 months period and one in the first six months period. Concomitant creatinine elevation was determined in three of five patients (2.5\%). The creatinine levels in these patients were $2.8,2.1$ and $3.3 \mathrm{mg} / \mathrm{dL}$, respectively. Table 1 shows the BKV DNA values, time to detection of positivity after transplantation and concomitant creatinine values. The results of the renal biopsy in these three patients wwere compatible with BKVAN. All the three patients were receiving mycophenolate mofetil (MMF), tacrolimus (FK) and prednisolone treatment, and found to have low-positive CMV DNA levels in the concomitant tests. MMF was reduced by $50 \%$, FK was decreased to the lowest dose and ciprofloxacin $500 \mathrm{mg} /$ day (renal adjusted) was started in the management of patients. In the follow-up, BKV DNA and creatinine levels returned to normal, and no graft loss developed in any of the patients.

A total of 23 patients (19.5\%) had CMV viraemia (57$7.33 \times 10^{4}$ copies $/ \mathrm{mL}$ ). Nineteen patients had a CMV DNA copy number of 57-500 copies/mL, while three patients had 501-10.000 copies/mL and one patient had $>10.000$ copies $/ \mathrm{mL}$. No CMV-related clinical or laboratory findings were detected in any of the patients. Ganciclovir $5 \mathrm{mg} / \mathrm{kg} 2 \times 1 \mathrm{IV}$ treatment was started upon consideration of CMV reactivation in one patient where $>10.000$ copies/mL was determined in the first six months after transplantation and three patients where a progressive increase was determined in CMV DNA values during follow-up. The therapy was maintained two more weeks after DNA was found to be negative. No relapse was detected in any patients after treatment. Table 2 shows the data of the treated patients. In patients, who were diagnosed as having BKVAN, there were concomitantly low levels of CMV viraemia.

Table 1. Viral load, creatinine and post-transplantation period of the patients with BK virus DNA level $>10^{4}$ copies/ $\mathrm{mL}$

\begin{tabular}{l|l|l|l}
\hline Patients & $\begin{array}{l}\text { Post-transplant } \\
\text { period }\end{array}$ & $\begin{array}{l}\text { Creatinine } \\
\text { (mg/dL) }\end{array}$ & $\begin{array}{l}\text { BKV DNA } \\
\text { (copies/mL) }\end{array}$ \\
\hline Case 1 & $>12$ months & 0.8 & $3.2 \times 10^{5}$ \\
\hline Case 2 & $6-12$ months & 0.9 & $2.2 \times 10^{6}$ \\
\hline Case 3 & $>12$ months & 2.8 & $5.4 \times 10^{6}$ \\
\hline Case 4 & $4-6$ months & 2.1 & $1.0 \times 10^{5}$ \\
\hline Case 5 & $>12$ months & 3.3 & $8.1 \times 10^{5}$ \\
\hline
\end{tabular}

BKV: BK virus

Table 2. Patients with cytomegalovirus DNA level >500 copies/mL and post-transplantation period

\begin{tabular}{l|l|l}
\hline Patients & Post-transplant period & CMV DNA (copies/mL) \\
\hline Case 1 & $4-6$ months & $7.3 \times 10^{4}$ \\
\hline Case 2 & $>12$ months & $6.6 \times 10^{3}$ \\
\hline Case 3 & $6-12$ months & $2.3 \times 10^{3}$ \\
\hline Case 4 & $>12$ months & $1.2 \times 10^{3}$ \\
\hline
\end{tabular}

CMV: Cytomegalovirus 


\section{Discussion}

Approximately $90 \%$ of the world's population is seropositive for BKV[6]. The incidence of BKVAN is $1-10 \%$ in renal transplant patients and leads to graft loss in $40-80 \%$ of these patients[15]. In a study by Rota et al.[16] investigating the BK and JC virus DNA positivity in the clinical samples of patients with high risk, one blood sample was found to be BKV DNA positive $(1 / 62 ; 1.6 \%)$. In a study by Yelken et al.[15] investigating BKVAN in patients with renal transplant, BKVAN was detected in $11(2.7 \%)$ of 412 patients, graft loss developed in two of three patients with acute rejection and kidney functions of other patients returned to baseline values. Almeras et al.[17] monitored the BKV DNA values in 119 renal transplant recipients with 6-month intervals, BK viraemia was detected in 13 patients (10.9\%); in 11 patients, viraemia became negative with reduction of immunosuppressive dose, one patient had decreased levels and one patient $(0.8 \%)$ had increased levels and developed graft rejection. In the same study, it was reported that $77 \%$ of patients developed viraemia within four months after transplantation[17]. In this study, BK viraemia developed in 12 of 118 patients, while BKVAN in three patients $(2.5 \%)$; one of the patients was within the first 6-month period after transplantation and two of them were in the $>12$-month period. No graft loss occurred in any of the patients. The incidence of BK viraemia and BKVAN in patients evaluated in our study was in line with the literature data. These data suggest that graft loss and dysfunction can be prevented by close monitoring of the patients and reducing the immunosuppressive doses at an early stage.

Although the incidence of graft-versus-host reaction has been reduced in recent years with the use of more potent immunosuppressive agents such as FK and MMF, the incidence of BKVAN in renal transplant recipients has increased as a result of potent immunosuppression provided with these drugs[18,19]. In a study by Ramos et al.[20] on diagnosis and treatment of BKV-induced nephropathy, it was found that in case of BKVAN detection, patients receiving one immunosuppressive agent [FK, cyclosporine A (CsA), sirolimus or MMF] and a steroid had lower renal graft loss and achieved higher viral clearance compared to patients receiving two immunosuppressive agents (FK, CsA or sirolimus, MMF) and a steroid.

Mengel et al.[19] reported that the risk of BKVAN was 13 times higher in patients receiving FK + MMF + methylprednisolone. In our study, three patients, who developed BKVAN, were also receiving MMF, FK and steroid treatment. Immunosuppression reduction remains the mainstay of treatment, however, viral clearance is often followed by acute rejection, likely secondary to a delay between immune reconstitution and viral clearance[21].
Burgos et al.[22] reported that immunosuppression doses must be reduced in case of BKV DNA levels $>10^{4}$ copies $/ \mathrm{mL}$, therefore, MMF dose can be reduced, CSA can be given instead of FK and intravenous immunoglobulins (IVIG) cidofovir, leflunomide and quinolones can be used, however, efficacy assessment of these options is difficult due to the lack of randomized controlled studies. In our study, MMF dose was reduced and ciprofloxacin was added to the treatment in patients developing BKVAN. Cidofovir and leflunomide are not available in Turkey, therefore, could not be used. However, it is unclear that reduction of immunosuppresive treatment alone would be helpful without adding ciprofloxacin.

Measurement of anti-BKV titers is an important tool to detect the onset of viral replication. In vitro co-incubation of BKV with human IVIG preparations caused 90\% inhibition of viral DNA after seven day in culture, a finding consistent with a direct neutralizing mechanism. This suggests a mechanism of protection via IVIG[23]. There are some other strategies aiming to prevent BKVAN. It has been shown that induction of a neutralizing antibody response by vaccination of kidney transplant patients immunologically naïve for certain subtypes before transplant may prevent replication of BKV and BKVAN. Furthermore, in a study, it was found that in vitro enrichment of BKV-specific T cells and subsequent adoptive T-cell transfer may improve the restoration of immunocompetence in kidney transplant recipients with BKV infection[24]. It is considered that vaccination of potential transplant recipients with $B K V$ antigens in conjunction with an adjuvant that induces cell-mediated immune response is a potential area for future research[21].

$\mathrm{CMV}$ is one of the opportunistic pathogens which is frequently encountered after SOT. It usually presents as asymptomatic infection in general population while it may present as primary infection or as reactivation of latent infection in patients undergoing organ transplantation. Cytomegalovirus infection usually occurs within 1-4 months after transplantation. It may be associated with acute and chronic graft loss. Şahin and Yalçın[11] have presented a case who developed CMV pneumonia five years after renal transplantation and emphasized that CMV infection may emerge in any period. Cytomegalovirus immunoglobulin $\mathrm{M}$, increased CMV immunoglobulin $\mathrm{G}$ titers and CMV antigenemia test (pp65) used for the diagnosis of CMV infection may be insufficient for diagnosis in patients receiving immunosuppressive treatment. Therefore, the most effective diagnosis method in patients with organ transplant is the CMV DNA assay[10]. In a study by Toyoda et al.[25] including 25 renal and 95 cardiac transplant recipients, clinical disease findings were detected in all patients with CMV DNA levels $\geq 500$ copies/ $\mathrm{mL}$ and few of the ones with lower viral load in peripheral blood using PCR. In another study carried out with renal, liver and bone marrow transplant recipients, baseline CMV viral load 
and the rate of increase were directly proportional to the risk for CMV disease[26]. In our study, a CMV DNA value of $>500$ copies $/ \mathrm{mL}$ was detected in 4 of 23 patients (17.4\%) and the patients were given ganciclovir treatment for two more weeks after viraemia was cleared. The immunosuppresive treatment was maintained. No CMV disease-related clinical or laboratory findings were determined in any of patients included in our study. This shows that the incidence of CMV infection is high, however, it is not generally associated with a clinical disease or organ rejection. Cytomegalovirus infection in renal transplant patients not only has direct effects but also indirect effects via low levels of viraemia. These indirect effects have been found to be associated with increased risk of rejection and graft dysfunction, atherosclerosis and opportunistic infections [27]. In our patients who were diagnosed as having BKVAN, there were concomitantly low levels of CMV viraemia. However, the role of CMV is not clear.

It is suggested that viral effects on patients and graft could be reduced by administering prophylaxis against CMV infection, especially during the first three months of intensive immunosuppressive treatment. In a recent study, Kır et al..[28] also showed less CMV infections in patients who had prophylaxis with valgancyclovir than in patients who had pre-emptive treatment $(4.4 \%$ vs. $30.1 \%$, respectively; $\mathrm{p}<0.001)$. However, late CMV infections were found to be significantly more frequent in prophylaxis receiving patients[28]. In one study investigating the pre-emptive approach, CMV viraemia was positive in $43.1 \%$ patients and there was end organ involvement (mostly gastrointestinal) in $21.5 \%$ which needed to be treated with antivirals. In addition, in 3.1\% CMV-related rejection episodes were found and eight patients in this study died due to CMV-related complications[29]. In one of our patients, CMV DNA was positive after three months of prophylaxis. These data show that the duration of prophylaxis must be individualized and could be prolonged. Routine monitoring of CMV DNA is still recommended especially for late $\mathrm{CMV}$ infection or for CMV DNA-positive patients.

There are some limitations of our study. The study cannot provide data to determine viral load threshold levels associated with graft dysfunction. We did not determine whether patients benefit from immunosuppressive treatment dose reduction or concomitant quinolone therapy in BKV infection. BK virus serology of the patients and therapies such as IVIG, leflunomide, cidofovir were not evaluated. However, this retrospective study with more than 100 patients well describes the prevalence of BKV and CMV infections in renal transplant patients and the effects of high viraemia on graft function.

\section{Conclusion}

Consequently, BKV and CMV are two major viruses which may reactivate and lead to infection in patients who undergo renal transplantation. Cytomegalovirus viraemia is common in renal transplant recipients and may be together with BKV. However, graft dysfunction and rejection rates are low with close monitoring, early diagnosis and treatment. Randomized, controlled studies with larger patient groups are necessary in order to determine the viral threshold levels associated with graft dysfunction or rejection, to decide the optimal management and to explain the role of concomitant infection.

\section{Ethics}

Ethics Committee Approval: Not needed. Retrospective study.

Informed Consent: Not needed. Retrospective study.

Peer-review: Externally and internally peer-reviewed.

\section{Authorship Contributions}

Surgical and Medical Practices: S.A., S.S.S., Design: S..K., S.A., S.S.S., Data Collection or Processing: S.A., Y.U., U.S., Analysis or Interpretation: U.S., Literature Search: S.A., Writing: S.A., Y.U.

Conflict of Interest: The authors declared no conflict of interest.

Financial Disclosure: The authors declared that this study received no financial support.

\section{References}

1. Cukuranovic J, Ugrenovic S, Jovanovic I, Visnjic M, Stefanovic M. Viral infection in renal transplant recipients. Scientific World Journal. 2012;2012:820621.

2. Polz D, Stec A, Polz-Dacewicz M. BK virus (BKV) - structure, epidemiology and pathogenesis. Journal of Pre-Clinical and Clinical Research. 2013;7:90-2.

3. Us D, Hayran M, Ustacelebi S. New human polyomavirus; BK virus antibody levels in different age groups using the hemagglutination inhibition test. Mikrobiyol Bul. 1991;25:173-7.

4. Coleman DV, Gardner SD, Field AM. Human polyomavirus infection in renal allograft recipients. Br Med J. 1973;3:371-5.

5. Coleman DV, MacKenzie FD, Gardner SD, Poulding JM, Amer B, Russel WJ. Human polyoma virus (BK) infection and ureteric stenosis in renal allograft recipients. J Clin Pathol. 1978;31:338-47.

6. Hirsch HH, Steiger J. Polyomavirus BK. Lancet Infect Dis. 2003;3:611-23.

7. Bohl LD, Brennan CD. BK virus nephropathy and kidney transplantation. Clin J Am Soc Nephrol. 2007;2(Suppl 1):36-46.

8. Ataman S, Colak D, Günseren F, Senol Y, Colak T, Aktekin MR, Gültekin M. Investigation of Cytomegalovirus Seroepidemiology in Antalya with a Population-Based Cross-Sectional Study and Review of Related Data in Turkey. Mikrobiyol Bul. 2007;41:545-55.

9. Us T. Cytomegalovirus. In: Topçu WA, Söyletir G, Doğanay M (eds). Enfeksiyon Hastalıkları ve Mikrobiyolojisi. İstanbul: Nobel Tıp Kitapevleri, 2008:167989.

10. Çolak D. Cytomegalovirus infeksiyonlarının laboratuvar tanısı. Klimik Dergisi. 2007;20(Suppl 1):257-60. 
11. Şahin G, Yalçın UA. Late development of Cytomegalovirus (CMV) infection in a Kidney Transplant Patient. Turk Neph Dial Transpl. 2007;16:198-200.

12. Babazadeh $A$, Javanian $M$, Oliaei $F$, Akbari $R$, Akbarzadepasha $A$, Bijani $A$, Sadeghi M. Incidence and risk factors for cytomegalovirus in kidney transplant patients in Babol, northern Iran. Caspian J Intern Med. 2017:8:23-9.

13. Karuthu $S$, Blumberg EA. Common infections in kidney transplant recipients. Clin J Am Soc Nephrol. 2012;7:2058-70.

14. Humar A, Michaels M; AST ID Working Group on Infectious Disease Monitoring. American Society of Transplantation recommendations for screening, monitoring and reporting of infectious complications in immunosuppression trials in recipients of organ transplantation. Am J Transplant. 2006;6:262-74.

15. Yelken MB, Kılıçaslan I, Çalışkan Y, Görgülü N, Yazıcı H, Türkmen A, Sever MŞ. BK Virus Nephropathy in Renal Transplant Recipients: A Single Centre Experience. Turk Neph Dial Transpl. 2009;18:117-22.

16. Rota S, Fidan K, Bozdayı G, Dalgıç A, Fidan I, Sucak G, Müderris T. Investigation of $\mathrm{BK}$ and $\mathrm{JC}$ virus DNA positivities by real-time polymerase chain reaction in the clinical samples of patients with high risk. Mikrobiyol Bul. 2011;45:280-7.

17. Almeras C, Vetromile F, Garrigue V, Szwarc I, Foulogne V, Mourad G. Monthly screening for BK viraemia is an effective strategy to prevent BK virus nephropathy in renal transplant recipients. Transpl Infect Dis. 2011;13:1018.

18. Nickeleit V, Hirsch HH, Zeiler M, Gudat F, Prince O, Thiel G, Mihatsch MJ. BK virus nephropathy in renal transplant-tubular necrosis, MHC class II expression and rejection in a puzzling game. Nephrol Dial Transplant. 2000;15:324-32.

19. Mengel M, Marwedel M, Radermacher J, Eden G, Schwarz A, Haller H, Kreipe $\mathrm{H}$. Incidence of polyoma virus nephropathy in renal allograft: Influence of modern immunosuppressive drugs. Nephro Dial Transplant. 2003;18:11906.
20. Ramos E, Drachenberg CB, Portrocarrarero $M$, Wali R, Klassen DK, Fink JC, Farney A, Hirsch H, Papadimitriou JC, Cangro CB, Weir MR, Bartlett ST. BK virus nephropathy diagnosis and treatment: experience at the University of Maryland renal transplant program. Clin Transpl. 2002:143-53.

21. Sharma R, Tzetzo S, Patel S, Zachariah M, Sharma S, Melendy T. BK Virus in Kidney Transplant: Current Concepts, Recent Advances, and Future Directions. Exp Clin Transplant. 2016;14:377-84.

22. Burgos D, Jironda C, Martin M, Gonzalez- Molina M, Hernandez D. BK virusassociated nephropathy. Nefrologia. 2010;30:613-7.

23. Vigil $D$, Konstantinov NK, Barry M, Harford AM, Servilla KS, Kim YH, Sun Y, Ganta K, Tzamaloukas AH. BK nephropathy in the native kidneys of patients with organ transplants: Clinical spectrum of BK infection. World J Transplant. 2016;6:472-504.

24. Weist BJ, Schmueck M, Fuehrer $H_{1}$ Sattler A, Reinke $P$, Babel N. The role of CD4(+) T cells in BKV-specific T cell immunity. Med Microbiol Immunol. 2014;203:395-408.

25. Toyoda M, Carlos JB, Galera OA, Galfayan K, Zhang X, Sun Z, Czer LS, Jordan SC Correlation of cytomegalovirus DNA levels with response to antiviral therapy in cardiac and renal allograft recipients. Transplantation. 1997;63:957-63.

26. Emery VC, Sabin CA, Cope AV, Gor D, Hassan Walker AF, Griffiths PD. Application of viral-load kinetics to identify patients who develop cytomegalovirus disease after transplantation. Lancet. 2000;355:2032-6.

27. Pérez-Sola MJ, Castón JJ, Solana R, Rivero A and Torre-Cisneros J. Indirect effects of cytomegalovirus infection in solid organ transplant recipients. Enferm Infecc Microbiol Clin. 2008;26:38-47.

28. Kır O, Zeytinoğlu A, Arda B, Yılmaz M, Aşçı G, Töz H. Impact of Prophylaxis vs Pre-emptive Approach for Cytomegalovirus Infection in Kidney Transplant Recipients. Transplant Proc. 2017;49:537-40.

29. Pretagostini R, Poli L, Lai Q, Russo G, Nudo F, Garofalo M, Melandro F, Gaeta A, Nazzari C, Fazio C, Di Simone E, Vullo V, Berloco PB. Pre-Emptive Therapy for the Treatment of Cytomegalovirus After Kidney Transplantation. Transplant Proc. 2017;49:638-41. 